\title{
A REPORT ON ARCHAEOLOGICAL INVESTIGATIONS OF OPEN HEARTH SITES IN SOUTHWEST QUEENSLAND
}

\author{
RICHARD ROBINS \\ Queensland Museum, Queensland Cultural Centre, South Brisbane \\ Queensland 4101
}

\begin{abstract}
This paper presents the results of test excavations on nine open hearth sites in the vicinity of the Currawinya Lakes, southwest Queensland. The hearths were all surface features constructed from silcrete cobbles, lumps of hardpan or a combination of both. The ages of six dated hearths ranged from c. $1700 \mathrm{BP}$ to c. $400 \mathrm{BP}$. This research demonstrates the potential for hearths to contribute to regional archaeological studies in Australia.
\end{abstract}

\section{Introduction}

In some areas of Australia the task of compiling chronologies or documenting other aspects of Aboriginal occupation can not be obtained from traditionally preferred deposits, such as rockshelter, cave or midden deposits, due either to their absence or unsuitability. In these circumstances, the investigation of open hearths may provide a source of valuable chronological and/or other cultural information.

In Australian archaeological practice, use of the term "hearth" has no accepted convention. In some cases terms such as "oven", "earth oven", "campfire" or "fireplace" are used in the literature to describe similar archaeological features, and the term "hearth" can be used to describe a range of dissimilar features (e.g. Balme and Hope 1990, Barbetti and Allen 1972, Dortch 1994, Jones 1973, Morwood and Godwin 1987, Smith et al. 1991). In this report, the term open hearth applies to discrete, relatively small (generally $<2 \mathrm{~m}$ diameter) roughly circular piles of ash-stained, heat fractured rock and/or lumps of burnt clay (referred to here as hearthstones), often associated with an ash-stained substrate and charcoal fragments, found on or in, open ground. Some may be associated with burnt floral or faunal remains, particularly bone and shell, and other cultural material, generally stone artefacts. These features are generally assumed to have been used for food cooking or heating, although in many cases the precise nature of their use is still speculative.

In southwest Queensland, numerous Environmental Impact Studies associated with the oil and gas fields of the Cooper Basin, combined with miscellaneous reports from diverse sources, present a picture of abundant archaeological evidence, predominantly surface stone artefact scatters, throughout the region (Robins 1993). However, few dates have been obtained from excavations of archaeological sites.

One of the major difficulties in obtaining well documented chronologies from sites in this area is the lack of suitable cultural deposits (Robins 1995). Reconnaissance surveys by the author of numerous rockshelters and overhangs formed in the soft Cretaceous sediments of Dissected Residuals of ranges in the region, particularly the Willies, Walters and Hoods Ranges, revealed few with occupation deposits. Of those with occupation deposits, most were shallow and disturbed (Personal Observation). Site reoords held in the Heritage Branch, Queensland Department of Environment, confirm these observations, with most of the rockshelter sites on record exhibiting similar characteristics. Exploratory test-pitting of three rockshelters with occupation deposits revealed that all were shallow and of relatively recent age with basal dates all less than 2000 years (Robins 1995). Other site types that might be suitable for dating, such as extensive middens or earth mounds, have not been recorded for this region. In the absence of these more suitable sites, one option for compiling a chronology of Aboriginal occupation is by dating open hearths.

Open hearths may not be the preferred source of archaeological excavation for a number of reasons. Each hearth probably only represents a limited number of events closely spaced in time, although it is possible that material from one hearth may be re-used in another, perhaps much younger hearth. For this reason, establishing regional occupational sequences from hearths dates is difficult. Unlike rockshelter deposits, they are also most likely to contain information relating only to a limited number of activities. In contrast to rockshelter deposits, which are to some degre protected from weathering and erosion, or many midden deposits which form their own protective microenvironment, open hearths are, as their name indicates, in the open and are relatively unprotected. They are therefore more likely to have boen subjected to erosion and weathering, with a subsequent accelerated loss of associated cultural and environmental information. This exposure may also have led to contamination, making some analyses, including dating, difficult. Finally, because hearths may be dug into a surface or covered by eroding sediments, a date derived from a hearth may not necessarily securely date the surface the hearth is on or in. However, while individual hearths do not represent long term occupations, they can be used to obtain a series of dates across the landscape. They are, therefore, suitable for testing hypotheses that postulate relationships between the archaeology and landscape processes.

Despite these limitations, open hearths have proved a valuable source for obtaining occupation dates for some areas of Australia where rockshelters are non-existent, including the Willandra Lakes in western NSW (Barbetti and Allen 1972), and Cooper Creek and the Strzelocki Desert in northeast South Australia (Smith et al. 1991, Veth et al. 1990). In each of these cases, dates obtained from hearths have been used to establish Pleistocene human occupation. However, the excavation of hearths, certainly 
for arid and semi-arid areas of Australia, is still relatively rare. Little is known about their use and construction, their relationship to other archaeological evidence or the environment and particularly about the potential of using hearths to address other archaeological issues, such as hearth con-struction and the factors governing raw material selection.

This paper presents the results of an exploratory investigation of nine open hearths in 1989, in an area of southwest Queensland commonly known as the Currawinya Lakes. This work was undertaken as part of a larger baseline regional study (Robins 1993). The aim of hearth investigation was to obtain some understanding of the form, composition and age of open hearths in the study area. Four localities were selected. In some cases, more than one open hearth at a locality was excavated. Descriptions of each of these excavations is given below.

\section{The Study Area}

The study area is approximately $655 \mathrm{~km}^{2}$ in area and falls within the pastoral property Kilcowera Station and the Currawinya National Park. The œntre of the study area lies at $144^{\circ} 15^{\prime \prime}$ west longitude and $28^{\circ} 45^{\prime \prime}$ south latitude, approximately $30 \mathrm{~km}$ northwest of the Queensland $/ \mathrm{New}$ South Wales border town of Hungerford. The dominant geographic feature of the area is an ephemeral lake system the most important lakes of which are Lake Wyara, a saltwater lake, and Lake Numalla, a freshwater lake. The anastomosing channels of the Paroo River are approximately $25 \mathrm{~km}$ to the east (Fig. 1). The lakes are situated on the extreme northwestern margin of the Darling River drainage system. Lake Numalla both feeds, and is fed by, the Paroo River system which in turn flows into the Darling River $200 \mathrm{~km}$ to the south of the Lakes. Lake Wyara, on the other hand, is the sink for a small internal drainage system which links with the Paroo River only during very high floods.

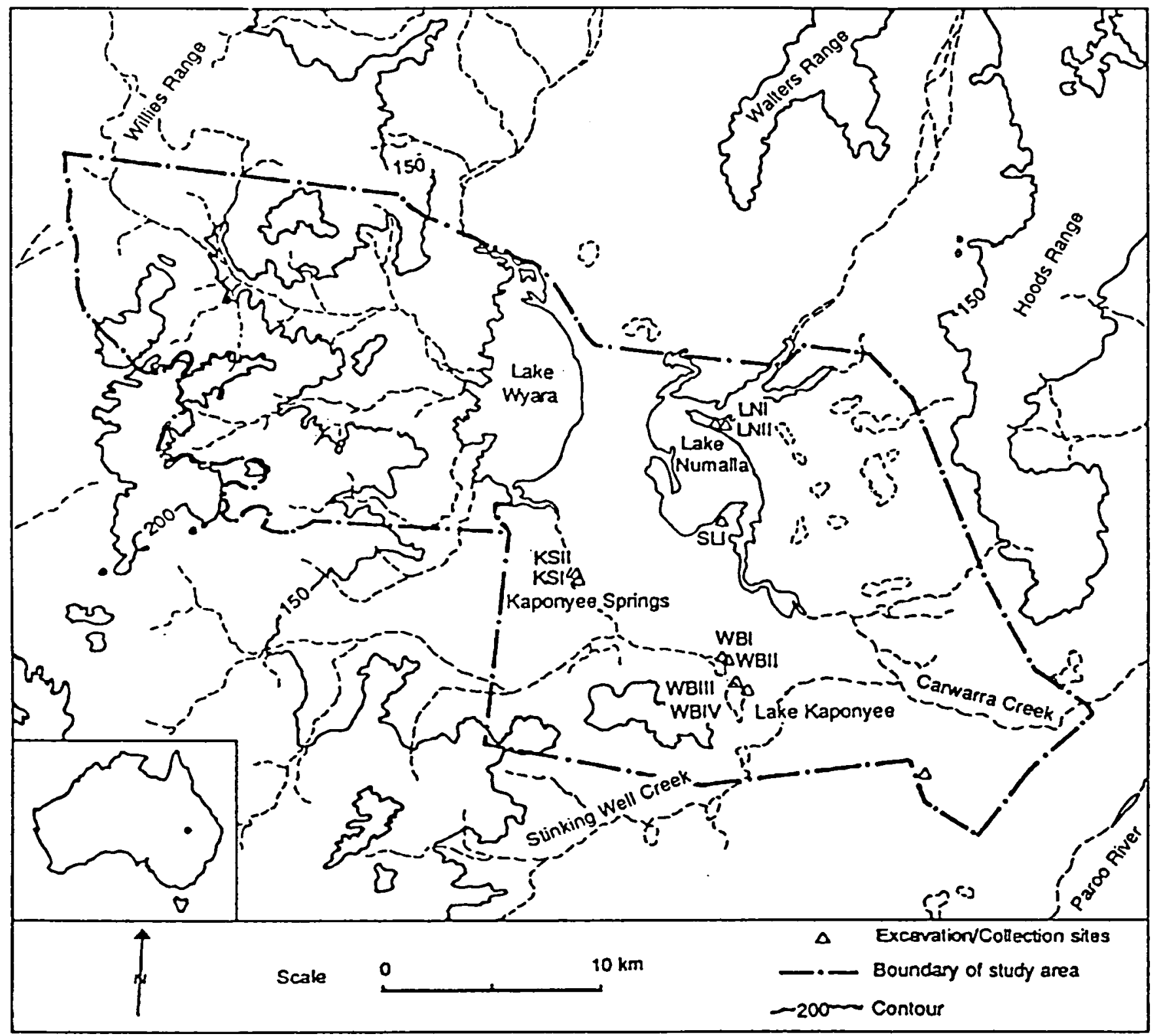

Figure 1. Study area showing the sites described. 


\section{Methods}

Despite extensive random and non-random survey, intact, in situ hearths proved difficult to find. Hearths could generally only be located by searching the edges of claypans or other surfaces where erosion had exposed hearths or parts thereof. Where possible, hearths chosen for investigation had minimal disturbance. In the cases where erosion was more extensive, the least eroded parts of the hearth were selected.

Hearth contexts were mapped using a plane table and optical alidade. Plans of the hearths were plotted onto grided paper from a string grid superimposed over the hearth. In two instances, excavated hearths were integrated into a cross-section traverse. After positioning a datum near the hearth, a $50 \mathrm{~cm}$ square was laid out over the portion of the hearth selected for excavation. The hearths were excavated following procedures outlined by Johnson (1979).

Descriptions of soil colours were obtained by using a Munsell Soil Colour Chart. Soil reaction was obtained using the colorimetric method. The excavated material was sieved through $2 \mathrm{~mm}$ and $4 \mathrm{~mm}$ wire mesh and the retained fraction kept for laboratory sorting and examination. A $100 \mathrm{~g}$ grab sample from the $<2 \mathrm{~mm}$ fraction for each Excavation Unit was retained for further examination. More details concerning these excavations accompany the detailed site descriptions following.

\section{Locality 1}

The first locality investigated is approximately midway along the length of the peninsula extending out into the northeastern end of Lake Numalla (Fig. 2). It lies in the Dynevor (D7) landsystem that comprises:

Low dunes less than $4 \mathrm{~m}$ high on old alluvial plains; mulga shrubby tall open shrubland; red earthy sand with grey and brown clays on the claypans and saltpans (Dawson and Boyland 1974).

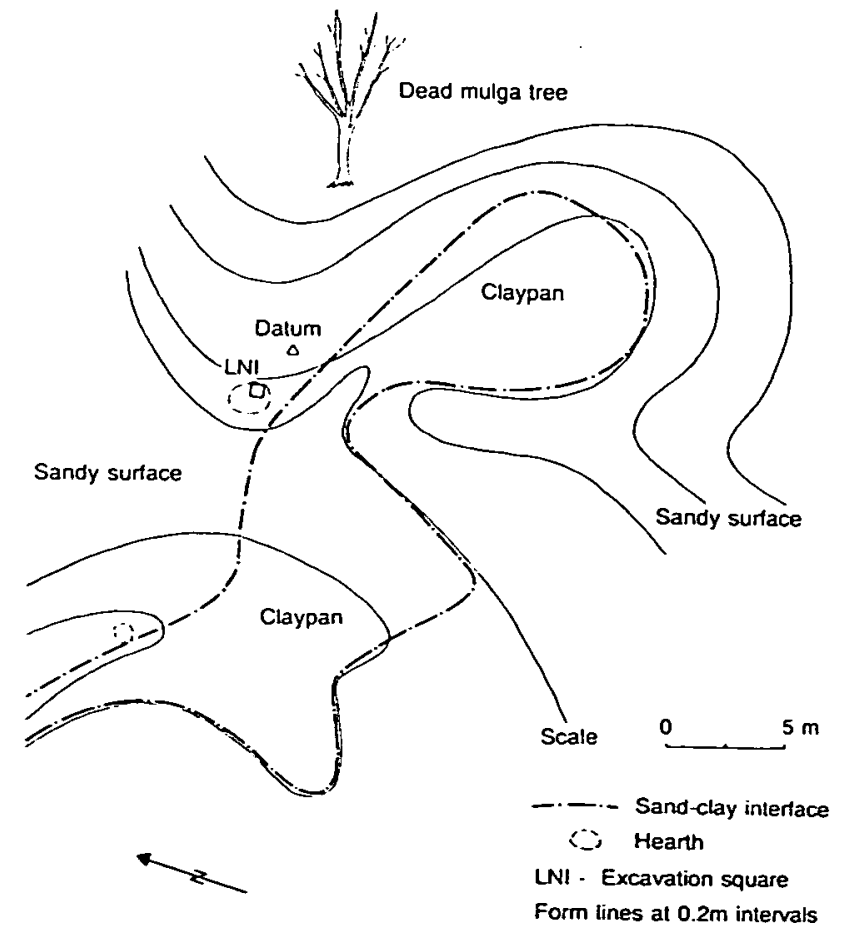

Figure 2. Site plan for Lake Numalla $L$
This locality represents the maximum distance from a stone source for any point in the survey area. Here two hearths were investigated.

\section{Lake Numalla I (LND)}

Lake Numalla $I$ is a small hearth eroding out of a loose sandy area onto a claypan which also contained some stone artefacts. This hearth is located $50 \mathrm{~m}$ south of the crest of the central ridge, and $250 \mathrm{~m}$ north of the lakes edge. It is situated on the boundary of a marked local topographic change with a break in slope to the west and southwest. At this point the large mulga (Acacia aneura) and other larger tree varieties give way to predominantly hopbush (Dodonaea sp.) and budda bush (Eremophila sturtii), many of which had died. Two claypans had formed to the west and southeast and both contain small numbers of artefacts (Fig. 2).

The hearth measures $80 \mathrm{~cm}$ (NS) $\times 60 \mathrm{~cm}(\mathrm{EW})$, and consists of irregularly-shaped lumps of clay up to $12 \mathrm{~cm}$ in diameter (Fig. 3). Approximately 30\% of its surface was covered in herbs and forbs. Clay lumps from the western end of the hearth had eroded up to $4 \mathrm{~m}$ downslope into the sandy apron and claypan and the surface adjacent to the hearth was deflating. Artefacts were found in the adjacent claypans and a second, eroded hearth was located approximately $10 \mathrm{~m}$ to the west.

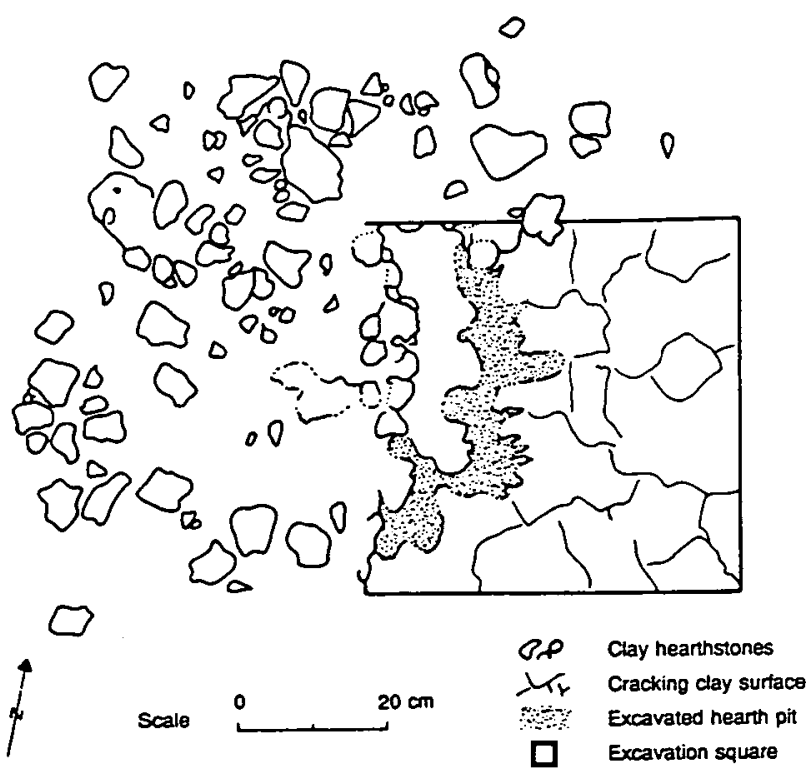

Figure 3. Plan of excavated Lake Numalla $I$.

\section{Excovation description:}

The $50 \mathrm{~cm}$ excavation square was placed on the uneroded upper slope of the hearth and was excavated in six Excavation Units to a mean depth of $9 \mathrm{~cm}$. Forty-one kilograms of deposit were removed. Excavation Unit 1 is predominantly reddish yellow (5YR 6/6) sand with some hearthstones. Some charcoal staining was observed around the hearthstones. Excavation Units 2 and 3 are similar in texture, although the charcoal staining in the northwestern comer increases with depth and the sand changes colour to 
light reddish brown (5YR 6/4). The hearthstones are friable and cracked. On the eastern side at the base of Excavation Unit 3 a hard, burnt and cracked layer of clay was encountered. This basal layer dips $6-8 \mathrm{~cm}$ towards the northwestern corner of the square (Fig. 4). Hearthstones and an associated ashy deposit continue down to the baked, basal clay. The heat from the fire has both cracked and hardened the clay layer on which it is formed. Small amounts of organic matter in the form of rootlets, twigs and bark were found throughout the non-hearth sediment. Soil reaction $(\mathrm{pH})$ was 7.0 throughout. Small amounts of good quality lumps of charcoal were found underneath the hearthstones. In one case charcoal resembling a short length of stick was wedged between two hearthstones.
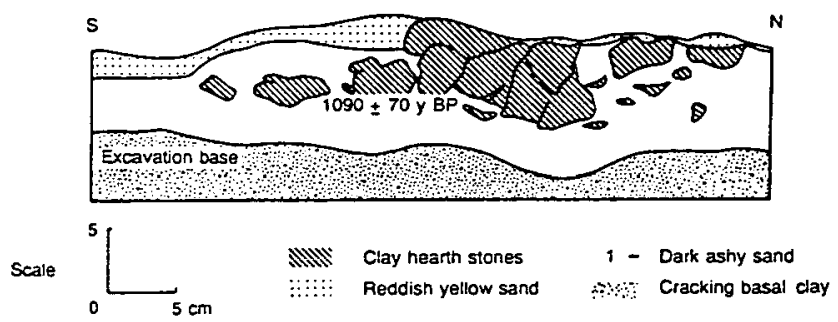

Figure 4. Cross-section of west face, Lake Numalla I excavation.

Charcoal submitted from this sample required quadruple counting time to give a ${ }^{14} \mathrm{C}$ date of $1090 \pm 70 \mathrm{BP}$ (Beta 33933). Three multi-platform cores, one retouched flake, one flake and one flaked piece, were found in the adjacent claypan. All are made from silcrete.

\section{Lake Numalla II (LNII)}

Lake Numalla II is a small hearth approximately $700 \mathrm{~m}$ southeast of LNI. It is situated just under the crest on the northern side of the ridge, $200 \mathrm{~m}$ south of the northern extension of the lake. This area is characterised by numerous small sandy hummocks and depressions. The hearth is eroding out of a sandy area onto the apron of a claypan.

The hearth consists a small number of irregularly shaped clay hearthstones (some with a diameter as large as $10 \mathrm{~cm}$ ), in an area measuring $50 \mathrm{~cm}$ (NS) $\times 50 \mathrm{~cm}$ (EW). Some of the hearthstones are fragmented. The hearth was covered by red sand and some small tufts of grass grew in it (Fig. 5).

\section{Excovation description:}

The $50 \mathrm{~cm}$ excavation square was laid out on the uneroded southern side of the hearth, and excavated in six Excavation Units to a mean depth of $14 \mathrm{~cm}$. Sixty-five kilograms of deposit were removed. Excavation Unit 1 is predominantly reddish yellow (5YR 6/8) sand with baked clay nodules. Plant material, including leaves, twigs and rootlets, is also present.

In Excavation Unit 2, the reddish yellow sand in the northern section gives way to an ashy, light reddish brown sand (5YR 6/3). The number of hearthstones also increases in this Unit. As the excavation progressed the ashy layer in the northern third of the square continued, while the sand in the remainder of the square graduated to a reddish brown (5YR 5/3). The ashy layer and hearthstones stopped at a mean depth of $12 \mathrm{~cm}$. The larger $(5-10 \mathrm{~cm})$ hearthstones increased in number down to Excavation Unit 2 and then diminished with depth (Fig. 6). Soil reaction (pH) remained 7.0 throughout. A probe was inserted into the sandy base of the excavation for a further $30 \mathrm{~cm}$ without striking a clay base. Unlike LN1, this hearth has been formed on or in a sandy substrate. Charcoal from Excavation Unit 2 gave a ${ }^{14} \mathrm{C}$ date of $1150 \pm 80 \mathrm{BP}$ (Beta 34206).

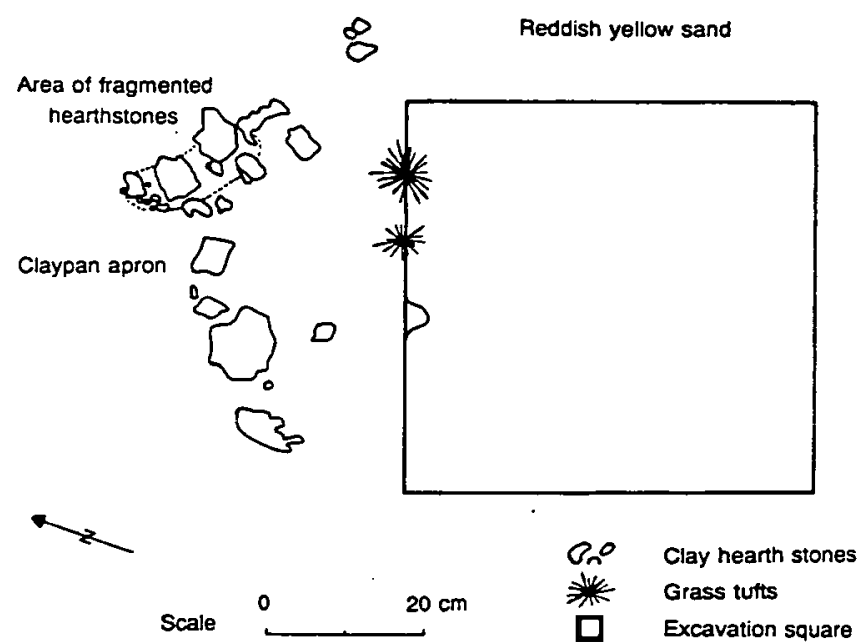

Figure 5. Plan of Lake Numalla $I$.

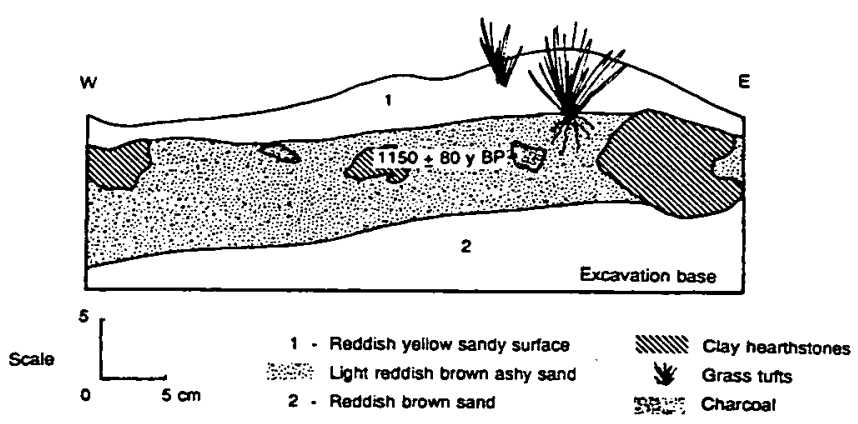

Figure 6. Cross-section of north face, Lake Numalla II excavation.

\section{Discussion:}

The two hearths investigated at this locality are similar in three respects. Both have similar dimensions, they have been constructed from irregularly shaped lumps of clay of similar size, and both are of a similar, late Holocene age. However, LNI was formed in a small pit excavated out of a compact clay layer. The lumps of clay from the excavation were then probably used as hearthstones. In the hard basal layer a number of distinct linear impressions up to $3 \mathrm{~cm}$ long and $4 \mathrm{~mm}$ wide, were noted These impressions have a semicircular profile and a smooth compact surface. They can be interpreted as the impressions left by a digging stick used for the initial excavation of the hearth. LNII, by comparison, had been dug into, or placed on, a sandy surface. The clay had been brought to this site from elsewhere. 


\section{Locality 2}

The second locality investigated is at the southern end of Lake Numalla, approximately $1.5 \mathrm{~km}$ west of the mouth of Carwarra Creek (Fig. 1). The dominant land system for this area is Dynevor Dunefield (D7) mixed with lesser amounts of Eulo Mulga Sandplains (S2). The sandplains are:

Flat plains with low slopes on the edges; mulga, poplar box shrubby tall open shrubland; sandy red earths with alkaline and neutral soil reaction trends (Dawson and Boyland 1974).

The feature selected for more detailed investigation was a hearth eroding into a claypan associated with a small stone artefact scatter. Hearths in close proximity to the lake were rarely found and the inclusion of this hearth enhanced both the spatial distribution and locational variability of the hearths sampled.

\section{South Lake I (SLD)}

South Lake I is a hearth eroding from sand into a small linear claypan (Fig. 7). It is approximately $150 \mathrm{~m}$ south of the edge of the lake in gently undulating sandy country that is dipping down towards the lake. The vegetation is predominantly hopbush and budda bush with the occasional tall eucalypt and mulga. The hearth measures $60 \mathrm{~cm}$ (NS) $x$ $40 \mathrm{~cm}$ (EW), with some hearthstones scattered up to $2 \mathrm{~m}$ into the claypan. The hearthstones are all of clay, some with a diameter of up to $10 \mathrm{~cm}$. A small number of artefacts $(<20)$ were scattered throughout the claypan and included a large, fire-cracked core, flakes, retouched flakes, grindstone fragments and ochre nodules. This number was considered too small for a reasonable sample and no collection was made.

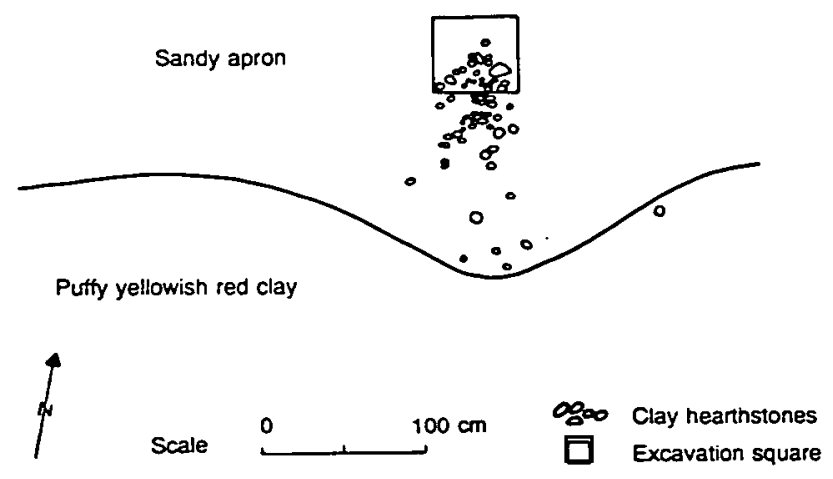

Figure 7. Plan of South Lake I.

\section{Excovation description:}

The $50 \mathrm{~cm}$ excavation square was placed at the uneroded southern end of the hearth and excavated in three Excavation Units to a depth of $9 \mathrm{~cm}$. The surface of Excavation Unit 1 consists of a very compact, ashy, dark roddish brown loam (5YR 3/2) surface layer with hearthstones embedded into it. Yellowish red (5YR 5/8) sand from the surrounding surface has encroached onto the southern third of the square. This hard ashy and hearthstone layer continues into Excavation Unit 2 but gives way to a hard darker yellowish red sandy loam (5YR 4/6).
The sediment in the northern half of Excavation Unit 3 is a darker yellowish red (5YR 4/6) sandy loam with a blocky texture. The deposit in the southern half of the square is softer and consists of a number of thin, discrete layers. There are no hearthstones visible below Unit 3 . The crosssection of the northern face is uncomplicated. A yellowish red sandy loam caps a harder, darker reddish brown, charcoal and hearthstone impregnated layer (Fig. 8). The western cross-section reveals more complex stratification with the hard dull ashy layers interleaved with lighter coloured layers (Fig. 9).

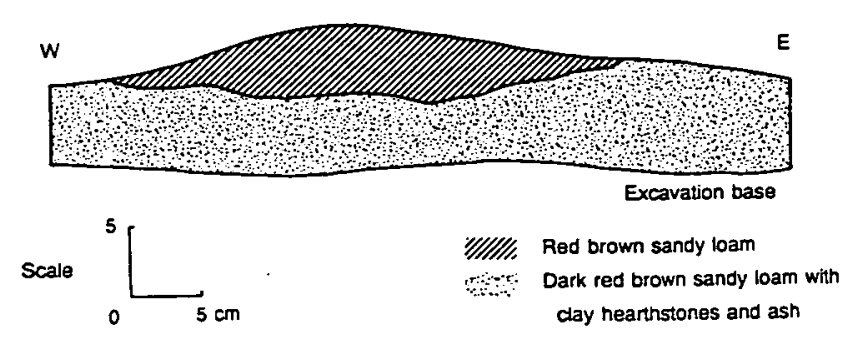

Figure 8. Cross-section of north face, South Lake I excavation.

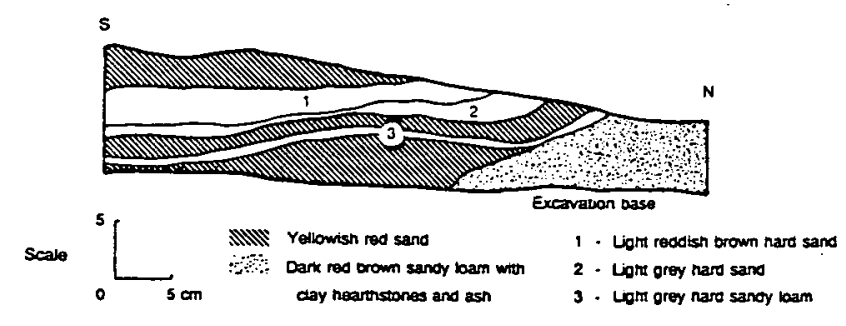

Figure 9. Cross-section of west face, South Lake I excavation.

\section{Discussion:}

This hearth was the only one found at this locality. The stratification visible in the western cross-section suggests that the hearth has been cut into a basal sandy loam that has become charcoal stained and heat affected (Fig. 9). As both the hearth and the surrounding areas have eroded, their respective materials have differentially co-mingled to produce this variegated stratigraphy. Insufficient charcoal was recovered to obtain a comventional ${ }^{14} \mathrm{C}$ date.

\section{Locality 3}

Locality 3 is at the northern ends of Lake Kaponyee and a smaller, adjacent unnamed lake, $5 \mathrm{~km}$ to the south of Lake Numalla (Fig. 1). These lakes are part of an arc of five ephemeral lakes formed at the eastern end of a ridge that projects into sandplain. The two northernmost lakes form part of the headwaters of Kaponyee Creek and flow west into Lake Wyara, while the remainder form the mid-oourse of Stinking Well Creek which flows into Carwarra Creek to the northeast. All these lakes are part of the Lake Pure landsystem which is described as: 
Major lakes subject to infrequent flooding, sparse vegetation with small areas of herb field and shrubland fringed with coolibah and river red gum woodland; structured grey clays and texture contrast soils (Dawson and Boyland 1974).

The lakes are all shallow and seasonal. Small, eroded lunettes have formed on their eastern margins while their western margins are bounded a ridge of Hard Mulga lands, whose surface is littered with silcrete gibber. This is the nearest source of stone material for artefact manufacture. The red earths of the Sandplain, which are at a higher relative elevation than the lunette, encroach onto the lunettes eastern and northern margins (Fig. 10). The coolibah (Eucalyptus microtheca) and river red gum (Eucalyptus camaldulensis) woodlands are only found at the northern and eastern ends of these lakes.

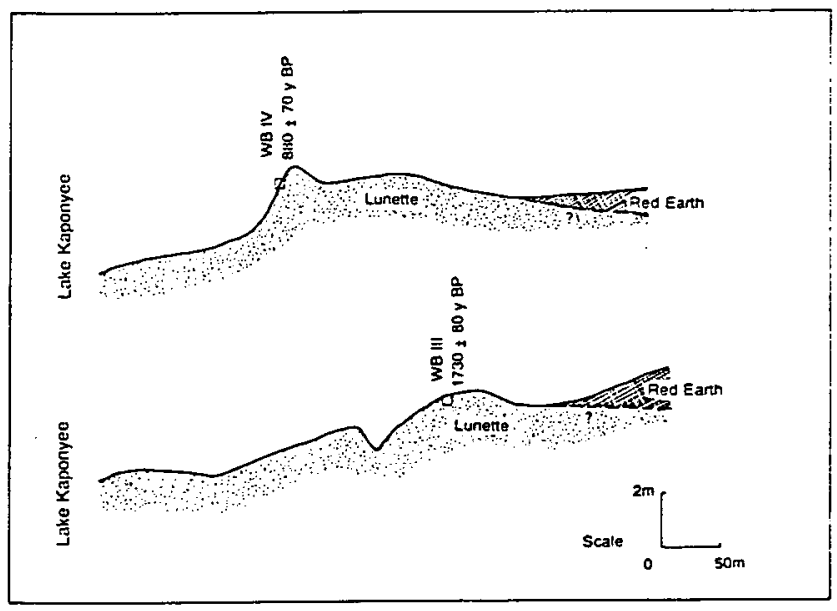

Figure 10. Topographic profiles of the Lake Kaponyee lunette.

A number of hearths are located in the woodlands of the lunettes at both these lakes. As these lunettes are assumed to be of Pleistocene age, hearths in/on them were investigated to determine if they were of a similar age. Four hearths, two from each lunette, were chosen for excavation. These hearths were titled Whites Bore I-IV, as Whites Bore, a defunct Bore several kilometres to the west, was the nearest identifiable point marked on the 1:250 000 topographic map sheet.

Whites Bore III and IV are amongst a number of stone and clay hearths located on the northern and northwestern end of the Lake Kaponyee lunette. At the northern end of the lake, a creek linking the two northernmost lakes bisects the lunette at the point where a low ridge of hard mulga land meets the lunettes. This ridge is the nearest source of stone material for hearthstones. The red earths at the back of the lunette, some $100 \mathrm{~m}$ to $150 \mathrm{~m}$ to the north are the presumed raw material source for the clay hearthstones. Within the first kilometre from the creek, the position, composition and distance from the creek of all hearths was noted. A total of 54 hearths were recorded including 17 stone hearths, 11 stone and clay hearths and 26 clay hearths. A graph comparing the cumulative frequency of each type against distance from the creek is presented in Figure 11. Clay hearths extend along the lunette for the full kilometre, while stone hearths occur only in the first $700 \mathrm{~m}$. This marks the limit people will carry stone in preference to using all-clay hearthstones. There is a zone of mixing where composite hearths made from both clay and stone are found. However, $88 \%$ of the stone hearths occur within the first $300 \mathrm{~m}$, while $96 \%$ of the clay hearths occur after the first $300 \mathrm{~m}$.

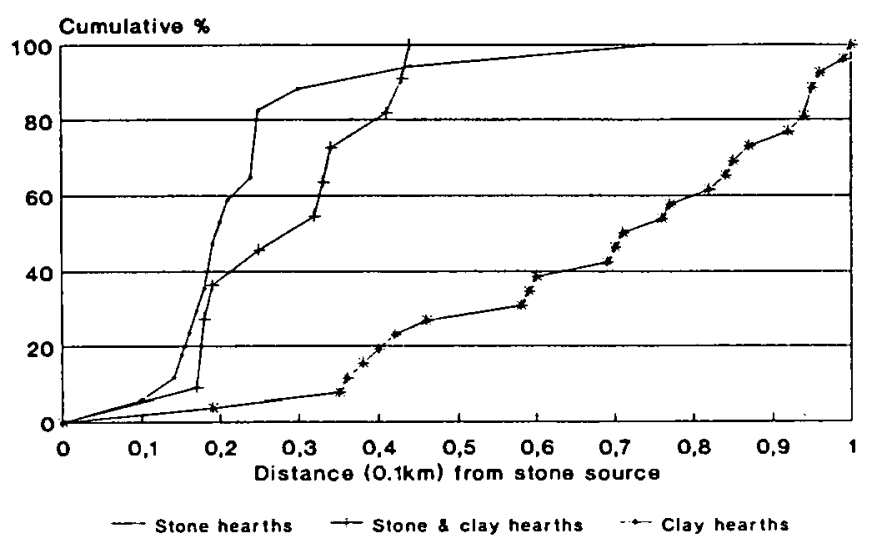

Figure 11. Cumulative frequency of hearth types from the nearest stone source, Lake Kaponyee.

\section{Whites Bore I (WB I)}

Whites Bore I and II are located on the inner slope of the lunette of the northernmost, unnamed lake, approximately one-third of the way down its length. They are $55 \mathrm{~m}$ northeast of the waters edge, $30 \mathrm{~m}$ southwest of the boundary between the sandy red earths and the lunette and $70 \mathrm{~m}$ southwest of the first ridge of sandy red earths in the Dynevor (D7) landsystem. The lunette clays are covered with a thin layer of medium-to-coarse white sand. With the exception of several saltbushes, the area around the hearth was bare of vegetation although there was a considerable amount of leaf litter and twigs on the surface.

Whites Bore I is an eroding clay hearth measuring $90 \mathrm{~cm}$ (NS) $x 130 \mathrm{~cm}(\mathrm{EW})$. Hearthstones from the eroded section of the hearth are scattered up to $4 \mathrm{~m}$ downslope (Fig. 12).

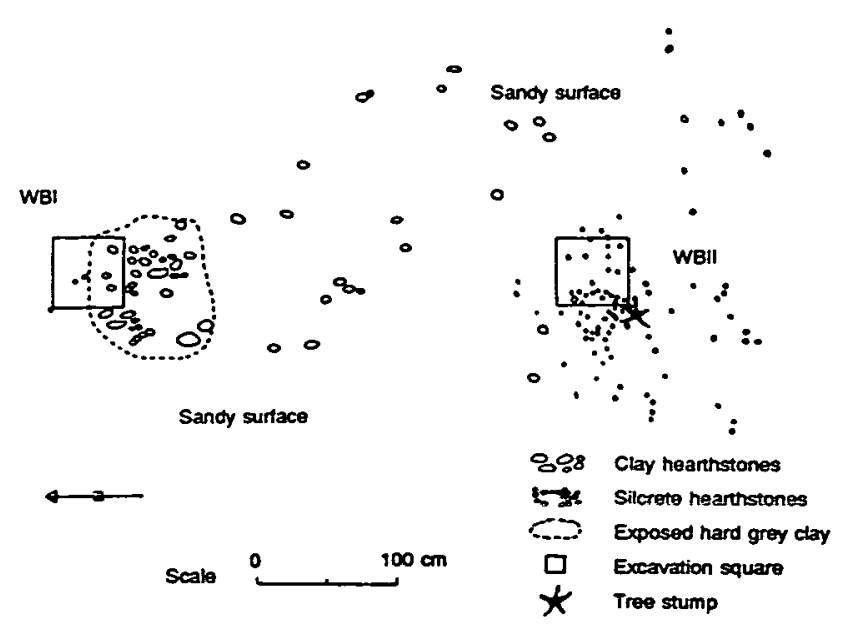

Figure 12 Plan of Whites Bore I and II. 


\section{Excovation description:}

An excavation pit was placed on the northern, upslope side of WBI. It was excavated in three Excavation Units to a mean depth of $6 \mathrm{~cm}$. Thirty-five kilograms of deposit were removed. A thin layer of medium to coarse, white, windblown sand overlies a pinkish grey (5YR 6/2) ash stained clay layer. Clay hearthstones, up to $12 \mathrm{~cm}$ in diameter, are embedded in the top $3-5 \mathrm{~cm}$ of this layer. The hearth rests on a hard, cracked and ash stained clay layer. The ash staining in the pit diminishes towards the north, away from the concentration of hearthstones. Hearthstones are concentrated in Excavation Unit 2 and only a few fragments are found in Excavation Unit 3 (Fig. 13). The associated lunette deposit contains organic matter in the form of leaves, roots, twigs and plant stems. There was insufficient charcoal in this hearth to provide a conventional ${ }^{14} \mathrm{C}$ date.

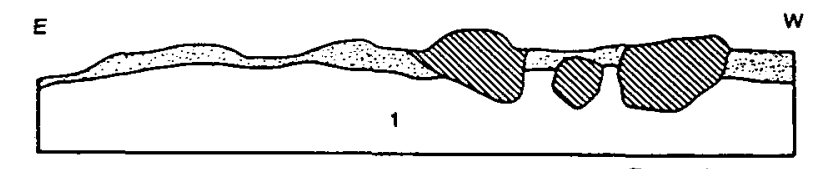

Scale

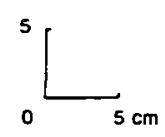

Excavation base

Figure 13. Cross-section of south face, Whites Bore I excavation.

\section{Whites Bore II (WB II)}

The WBII is located $3.5 \mathrm{~m}$ to the south of WBI. It measures $90 \mathrm{~cm}$ (NS) $\times 100 \mathrm{~cm}$ (EW) (Fig. 12). Hearthstones from it are scattered up to $4 \mathrm{~m}$ downslope and it appeared to be more eroded than WBI.

\section{Excovation Description:}

An excavation pit was placed on the northeastern side of WB II and it was excavated in one excavation unit to a mean depth of $5 \mathrm{~cm}$. Ten kilograms of deposit were removed. The erosion of this site is well advanced and none of the hearthstones appeared to be in situ. While both fire cracked, coarse grained silcrete fragments and clay nodules are used as hearthstones, the silcrete predominated. The maximum diameter of the silcrete hearthstones is $8 \mathrm{~cm}$, and the clay $6 \mathrm{~cm}$. A fire cracked, snapped silcrete flake was found in this unit.

\section{Whites Bore III}

Whites Bore III is a clay and stone hearth situated on the southem side of the Lake Kaponyee lunette, approximately $700 \mathrm{~m}$ to the east of the creek. To the south, an erosion gully has intersected the lunette at an oblique angle to produce two low ridges. The hearth is on the second, or northernmost ridge (Fig. 10). Small stands of coolibahs grow $20 \mathrm{~m}$ to the southeast and $50 \mathrm{~m}$ to the southwest. Saltbush, forbs and bassias are the predominate ground cover.

WB III is approximately $20 \mathrm{~cm}$ above the surrounding surface. The remains of small shrub are on the southwestern side of the hearth and some grasses and saltbush grow in it The hearth is $130 \mathrm{~cm}$ (NS) $\times 50 \mathrm{~cm}$ (EW) with clay hearthstones up to $12 \mathrm{~cm}$ in diameter. Hearth fragments are scat- tered up to $4 \mathrm{~m}$ to the south. The remains of a stone hearth were evident $10 \mathrm{~m}$ to the southwest. A low density scatter of artefacts, including 2 tula slugs and a backed blade were observed on the downslope. Eleven stone artefacts and several pieces of unfired silcrete stones lay on the surface of the hearth (Fig. 14). The stone artefacts included 5 retouched flakes, 3 flakes, 1 backed blade and 2 snapped flakes. In view of the position of the hearth on the slope, it is not possible to determine if the artefacts had been discarded on the hearth or had deflated down onto the hearth surface.

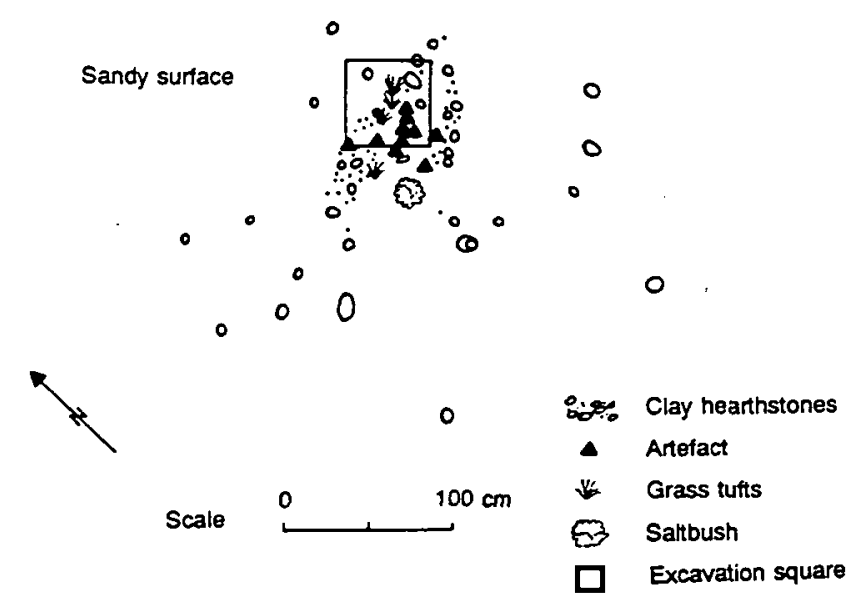

Figure 14. Plan of Whites Bore III.

\section{Excavation description:}

The excavation pit was placed on the upslope, northwestern side of the hearth. The hearth was excavated in three Excavation Units to a mean depth of $12 \mathrm{~cm}$. Thirty-seven kilograms of deposit was removed. A thin veneer of white, medium-to-coarse, windblown sand covers a puffy grey (5YR 6/2) clay in which the hearthstones are embedded. The clay associated with the hearthstones is soft and ashstained. The hearthstones, which diminish in number from the surface to base, are crumbly in parts and heavily carbonised. The clay at the base of the pit is more compact, darker (7.5 YR 6/4) and has formed into small peds. It dips down at the southwestern comer of the pit, where the hearthstones and burnt clay are concentrated (Fig. 15). This, and the distinct boundary between the ashy layer and the adjacent clay, indicates that the hearth has been formed in a shallow depression, although there are no signs of excavation. Small tree roots (unburnt) and insect burrows are present throughout the pit. Charcoal from Excavation Unit 1 was dated to $1730 \pm 80$ BP (SUA 2942).

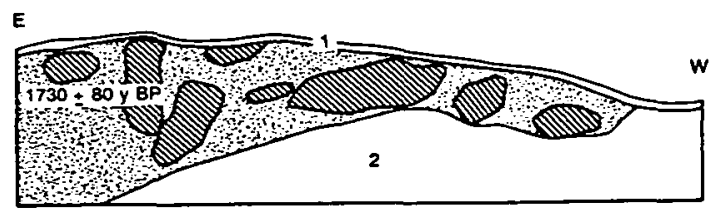

Exeavation base

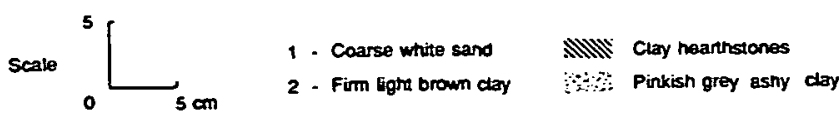

Figure 15. Cross-section of south face, Whites Bore III excavation. 


\section{Whites Bore IV}

Whites Bore IV is a clay and stone hearth located approximately $400 \mathrm{~m}$ southeast of the creek at the northern end of Lake Kaponyee. It is $50 \mathrm{~m}$ northeast of the lakes edge and $20 \mathrm{~m}$ southwest of the crest of the lunette (Fig. 10). A belt of large coolibah trees grow approximately $20 \mathrm{~m}$ to the south. The crest of the lunette is vegetated with hopbush, beyond which is gently undulating country with swales vegetated with saltbush, herbs and forbs. Approximately $200 \mathrm{~m}$ to the north the ground rises slightly to give way to the Dynevor (D7) sandplain. The hearth measures approximately $170 \mathrm{~cm}(\mathrm{NS}) \times 100 \mathrm{~cm}$ (EW) and contains clay hearthstones up to $10 \mathrm{~cm}$ in diameter and silcrete hearthstones up to $12 \mathrm{~cm}$ in diameter. It has begun to erode and hearthstones are starting to scatter (Fig. 16). The surface in which the hearth is sitting is red sandy earth overlain by a thin veneer of medium-to-coarse windblown, white sand.
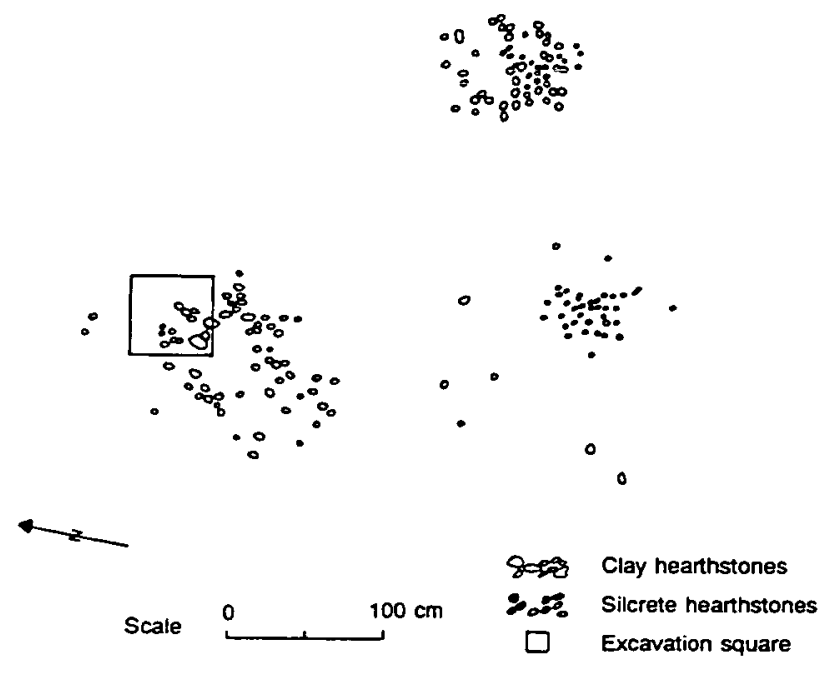

Figure 16. Plan of Whites Bore IV.

\section{Excavation Description:}

The excavation pit was placed on the northern side of the hearth and excavated in four Excavation Units to a mean depth of $9 \mathrm{~cm}$. Clay and stone hearthstones, up to $9 \mathrm{~cm}$ in diameter, in a red (2.5YR 4/6) ashy sandy loam are concentrated in the southeastern comer of the pit. This unit rests on a hard thin pinkish grey (5YR 7/2) cracking clay layer. The northwestem portion of the pit comprises a sandy yellowish red (5YR 5/6) earth which also lies on the hard cracking clay. A thin layer of this unit also covers the hearthstones. The hard thin grey clay lies on a reddish brown (5YR 5/4) sandy clay. As it was evident that the hearth does not intrude into the reddish brown layer but lies on top of the thin cracking clay, the excavation was terminated at this point (Fig. 17). The clay nodules appear to overlie the stone hearthstones, perhaps indicating multiple use. The hearthstones are concentrated in the upper two units, and only four nodules were recovered from Excavation Unit 4. Quadruple counting time on a small sample of fine powdery charcaal from Excavation Unit 3 (6cm depth) gave a ${ }^{14} \mathrm{C}$ date of $880 \pm 70 \mathrm{BP}$ (Beta-33937).

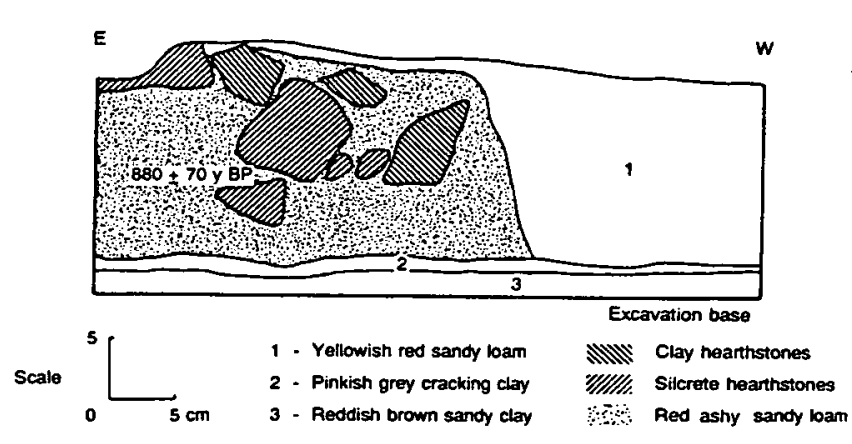

Figure 17. Cross-section of south face, Whites Bore IV excavation.

\section{Discussion:}

This locality was characterised by a relatively large number of clay, stone and stone and clay hearths. The poor quality charcoal associated with these hearths made dating difficult using conventional radiometric methods. The two dates that were obtained indicate that these hearths are late Holocene in age. They also imply that hearths have been used at this locality over a period spanning at least 1000 years. They have been constructed and used on the Pleistocene lunette and are not eroding out of it. In one case, that of WBIV, there are indications that the hearth may have been used more than once. Evidence for other cultural activities undertaken at the same time as the hearth use, is weak. Although stone artefacts were found in the proximity of the hearths, there was no evidence that the hearths and artefacts had contemporaneous use. The hearth survey results indicate that the preference for the type of heat retainer is governed by access to raw materials. Three hundred metres represents a clear demarcation in the distance people will carry stone for hearthstones before switching to an alternative source for heat retainers.

\section{Locality 4}

Kaponyee Springs is situated on a low rise approximately $5 \mathrm{~km}$ southeast of Lake Wyara, $5 \mathrm{~km}$ southwest of Lake Numalla and $500 \mathrm{~m}$ northeast of Kaponyee Creek (Fig. 1). It occurs in Dunefields/Mulga Sandplains (D7/S2) landsystems. The focus of the extensive archaeological site at this location is a number of low mound springs (now dried up) that have enupted in plains with low rounded dunes interspersed with claypans. The mound springs presumably afforded a source of permanent water. A spring still provides water for a tank on the site although it is suitable only for stock. Large claypans to the north can hold water for up to two months after rain (personal observation). The nearest source of stone from the site are the silcretes in the Hard Mulga Lands and associated creek systems, approximately $3 \mathrm{~km}$ to the south.

Two hearths at this locality were selected for test excavation. The hearths, which lay $600 \mathrm{~m}$ to the northeast of the mound springs, are termed Kaponyee Springs II (a and b) (KS Ila and $\mathrm{KSIlb}$ ). Descriptions of these excavations follow. 


\section{Kaponyee Springs II (a) (KSII (a))}

These hearths are located in an area of low Holocene dunes with mulga, poplar box (Eucalyptus populnea) shrubby tall open shrubland and claypans, some with lignum (Muelhenbeckia cunninghamii) in them. The top of the dune in which the hearths were located is approximately $1.5 \mathrm{~m}$ higher than outcropping hardpan visible in nearty claypans. Two hearths in close proximity to each other are eroding out of the dune into the northern side of an irregularly shaped claypan (Fig. 18). This claypan intersects small dunes to the west and run-off gathered in it runs into a larger claypan with lignum. As a consequence, a shallow erosion gully has formed at its base. Carbonate nodules and a number of artefacts were exposed on the floor of the claypan. They were too few for a reasonable sample and were not collected. Another claypan occurs $10 \mathrm{~m}$ to the east. To the south, shrubs grow on numerous small sand dunes. Extensive pig rooting of the sand dune surface was observed $10 \mathrm{~m}$ to the north. In nearby claypans to the south hardpan outcrops had been exposed.

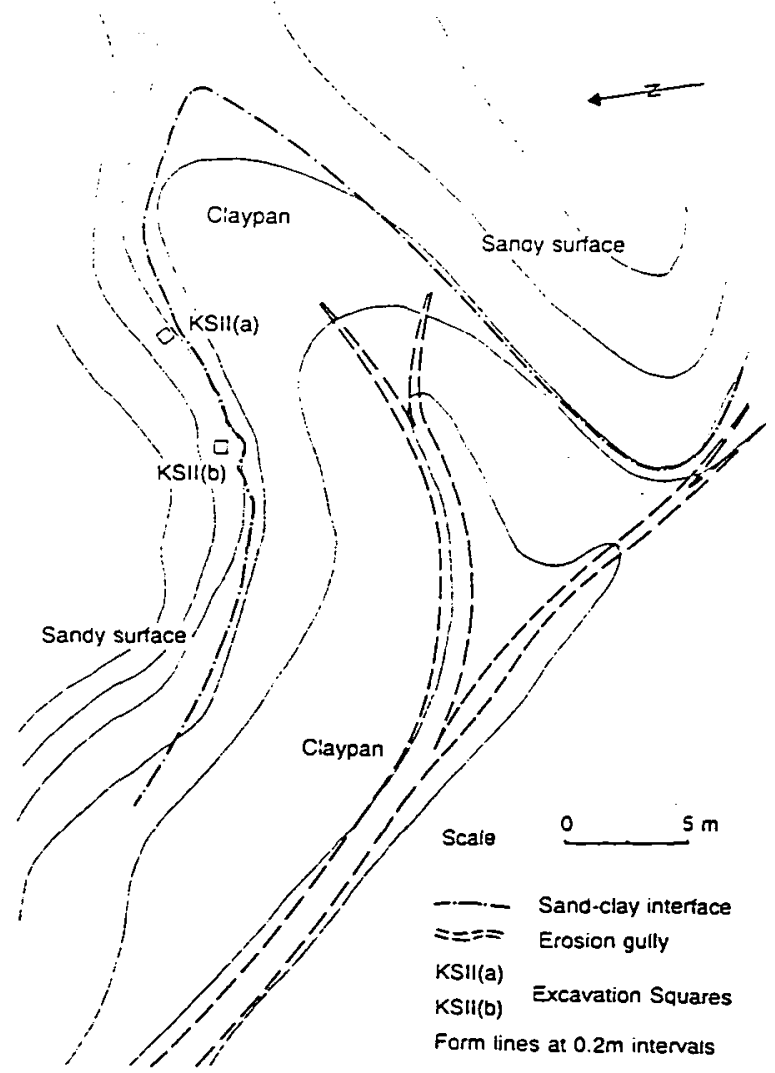

Kaponyee Springs II - Site Plan

Figure 18. Plan of Kaponyee Springs II (a) and II (b).

Kaponyee Springs II (a) measures $90 \mathrm{~cm}$ (NS) $\times 60 \mathrm{~cm}$ (EW) and consists of baked clay nodules of varying size up to $7 \mathrm{~cm}$ in diameter. The southern portion of the hearth is eroding down the slope of the claypan apron (Fig. 19) and pieces of hearthstone are scattered up to $3 \mathrm{~m}$ into the claypan.

\section{Excovation Description:}

The $50 \mathrm{~cm}$ excavation square was placed on the uneroded northern section of the hearth. Sixty-one kilograms of deposit were removed in four Excavation Units to a mean depth of $17 \mathrm{~cm}$. The hearth is in a red (2.5YR $5 / 8)$ fine to coarse sand that becomes slightly darker (2.5YR 4/8) and less coarse with depth. The soil reaction $(\mathrm{pH})$ is 7.0 for the upper three units and 7.5 for the basal unit. Rootlets are found throughout. The pit intersects the northern edge of the hearth. Hearthstones and associated ashy sediment are found only in the southern third of the deposit. As excavation proceded, the ashy sediment in the square diminished, although the number of hearthstones increased with depth to the base of Excavation Unit 3. Two silcrete flakes, one heat affected, were recovered from Excavation Units 1 and 2 (Fig. 20). A small charcoal sample from Excavation Unit $3(8-14 \mathrm{~cm})$ required quadruple counting time to give a ${ }^{14} \mathrm{C}$ date of $400 \pm 110 \mathrm{BP}$ (Beta-33931).

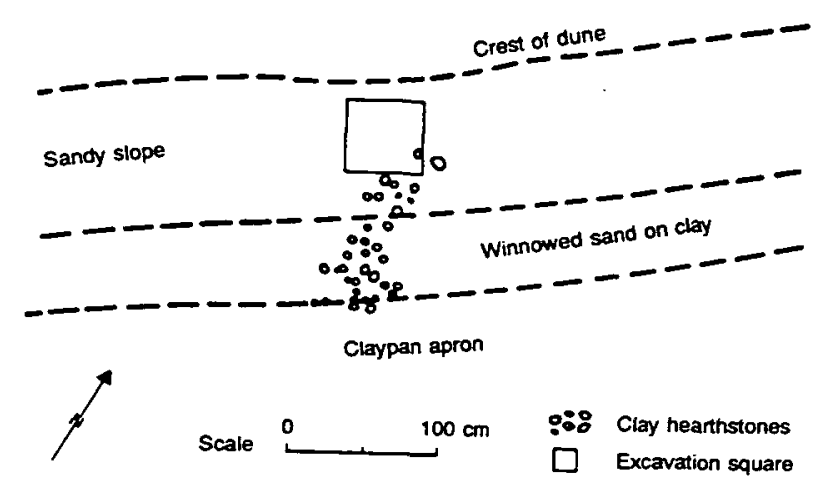

Figure 19. Plan of Kaponyee Springs II (a).

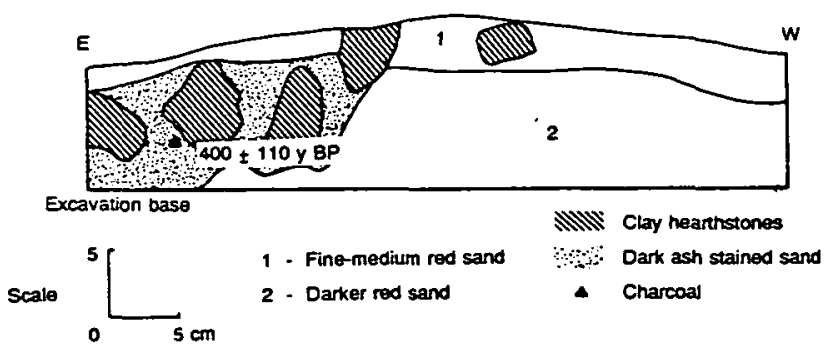

Figure 20. Cross-section of south face, Kaponyee Springs II (a).

\section{Kaponyee Springs II (b) (KS II (b))}

Kaponyee Springs II (b) is located $5.5 \mathrm{~m}$ to the southwest of $\mathrm{KSI}(\mathrm{a})$. It also is eroding out of the sand dune into the claypan. It measures $90 \mathrm{~cm}$ (NS) $\times 60 \mathrm{~cm}$ (EW) and consists of baked clay nodules up to $9 \mathrm{~cm}$ in diameter (Figs 18, 21). Eroded hearthstones are scattered up to $2 \mathrm{~m}$ into the claypan.

\section{Excavation Description:}

The $50 \mathrm{~cm}$ excavation square was placed on the uneroded northern section of the hearth. Forty-five kilograms of deposit were excavated to a mean depth of $8 \mathrm{~cm}$ in three 
Excavation Units. The hearth is in a red (2.5YR 5/8) fine to coarse sand with a constant soil reaction $(\mathrm{pH})$ of 7.0 throughout. It is more eroded than II(a) and the hearth was only intersected in the south-western comer. It comprises an ashy sand layer with clay hearthstones, dipping to the west. Hearthstones are concentrated in Excavation Unit 2. A silcrete flake was found in Unit 1. There is clear delineation between the hearth and the sandy deposit it is in (Fig. 22). A sample of charcoal from Excavation Unit $3(6-10 \mathrm{~cm})$ gave $\mathrm{a}^{14} \mathrm{C}$ date of $430 \pm 70 \mathrm{BP}$ (Beta 35210).

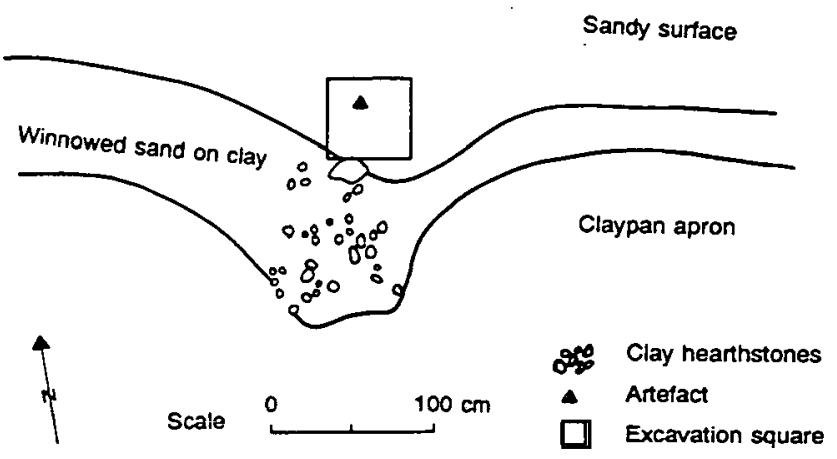

Figure 21 Plan of Kaponyee Springs II (b).

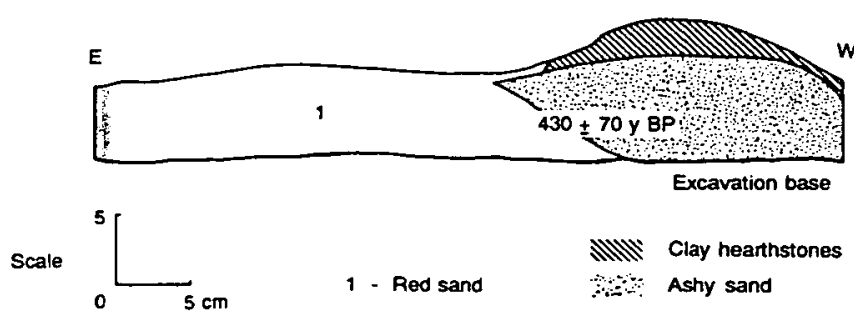

Figure 22 Cross-section of south face, Kaponyee Springs II (b).

\section{Discussion:}

These hearths provided the youngest ages for any of the dated hearths. The diminishing size with depth and the clear delineation between the ashy deposit and the surrounding sand indicate that these hearths have been dug out of the sand dune and used at roughly the same period. Both comprise irregularly shaped clay nodules used as heat retainers and it is likely that these originally came from hardpan exposed in nearby claypans. Only one stone artefact was found in direct association with these hearths, and it was not possible to determine the range of cultural activities associated with the hearth use.

\section{Discussion}

Nine hearths in four widely separated localities in the eastern half of the study area were investigated; seven comprising clay hearthstones and two using a combination of silcrete and clay. Many of the hearths proved difficult to date. Sufficient material could not be obtained from three to provide a conventional ${ }^{14} \mathrm{C}$ date, and quadruple counting times were required on samples submitted from three others. The dates obtained were all from the Late Holocene and ranged over about 1330 years $(400 \pm 100$ BP to $1730 \pm 80$ ). At localities 1 and 4 the dates overlap, although the hearth use between localities could be separated by nearly 1,000 years. At locality 3 the dates imply that hearths have been used at this locality for a long period of time -1000 years.

The maximum size of the hearths was $1.3 \mathrm{~m}^{2}$, the minimum $.2 \mathrm{~m}_{2}$ with a mean size of $.6 \mathrm{~m}_{2}$. The maximum dimension was $1.7 \mathrm{~m}$. Given the degree of erosion occurring at the sites and the nature of the excavations, these figures can only be considered a rough guide to hearth size. These sizes fall within the range of sizes for ethnographically recorded campfires (e.g. Robins and Trigger 1989). The depth of the hearths varied from between 5 and $17 \mathrm{~cm}$, but again, given the nature of sites and the erosion occurring on them, this figure again can only be used a rough indication of depth. Clear evidence for the excavation of the hearth pit into the substrate was obtained from four of the excavations.

The maximum size for both clay and stone hearthstones is $12 \mathrm{~cm}$. The mean maximum size is $10 \mathrm{~cm}$ suggesting a size threshold for the choice of hearthstones. The clay hearthstones were all irregular in shape, and were probably obtained locally from either digging into the hardpan substrate, or from nearby outcropping hardpan. Wright (1983:252) describes hardpan as

... a typically red to red-brown (2.5YR $4 / 6$ or 5/6-5/8 moist) vesicular indurated material, extremely hard both wet and dry. Structure is usually strongly but irregularly platy, or may be blocky. Black manganiferous accumulations are characteristic and occur on the surface or within peds. Irregular vertical partings often occur: secondary carbonate, where present coats these and aggregate faces, but may be absent within peds. Fractures and cleavage faces usually have a dull and porous earthy appearance.

Hardpan, with its vesiculated and indurated character, can superficially resemble termite mound. However, the strong resemblance of the clay hearthstone material to the hardpan description, the ubiquity of hardpan throughout the study area and the infrequent occurrence of termite mounds indicates hardpan as the source of the clay hearthstones. The silcrete originated from the hard mulga lands abutting the sandplains. From the evidence of the distribution of stone and clay hearths on the lunette of Lake Kaponyee, $300 \mathrm{~m}$ represents the threshold distance for preference of stone over clay.

Evidence of other activities carried out at the time of hearth use could not be ascertained. In one case there is evidence to suggest that the hearth had been used twice and in another five cases, the hearths were associated with stone artefacts. However, there was no clear temporal asscciation between the artefacts and the hearths. In two cases artefacts were found within the hearth, but there are insufficient numbers to draw any conclusions about the nature of the association. 


\section{Conclusion}

In addition to providing ages for archaeological features in an area of arid Australia that has had almost no information on the age of Aboriginal occupation, open hearths have provided a glimpse of the behaviours associated with their use, including raw material selection and methods of hearth construction. This exploratory investigation indicates that open hearths have the potential to provide a range of valuable archaeological information that complement other avenues of archaeological investigation.

\section{Acknowledgments}

I would like to thank Andrew Robins and Alan Hill for their assistance in the field, and Reg Hambelin for permission to work on Currawinya. J. Hall and Grant McTainsh provided support and advice on the field strategy and made comments on the draft text. John Richter drew the map and plans. Mike Barbetti and Gillian Taylor provided advice and assistance on ${ }^{14} \mathrm{C}$ dating. The Queensland Museum supported the fieldwork and provided funds. The Australian Heritage Commission, through the National Estates Program also assisted with funds. I would like to thank all involved for their support without which this work would not have been possible.

\section{References Cited}

BALME, J. and HOPE, J. 1990 Radiocarbon Dates from Midden Sites in the Lower Darling River Area of Western New South Wales. Archaeology in Oceania. 25(3):85-101.

BARBETTI, M. and ALLEN, H. 1972 Prehistoric Man at Lake Mungo, Australia, by 32,000 years BP. Nature. 240:46-48.

DAWSON, N. M. and BOYLAND, D. 1974 Land Systems. in Western Arid Landuse Study, Part 1.
Queensland Department of Primary Industry Division of Land Utilisation Technical Bulletin No. 12. Appendix VII. Brisbane.

DORTCH, J. 1994 Pleistocene Radiocarton Dates for Hearths at Tunnel Cave Southwestern Australia. Australian Archaeology. 38:45-47.

JOHNSON, I. 1979 The Getting of Data. Unpublished Ph.D. thesis. Australian National University. Canberra.

JONES, R 1973 Emerging Picture of Pleistocene Australians. Nature. 246:278-281.

MORWOOD, M. J. and GODWIN, L. 1987 Archaeology of the Gyranda Region, Central Queensland. Queensland Archaeological Research. 4:96-114.

ROBINS, R. 1993 Archaeology and the Currawinya Lakes: Towards a Prehistory of Arid Lands of Southwest Queensland. Unpublished Ph.D. Griffith University. Brisbane.

ROBINS, R 1995 The Results of Test Excavations in Three Rockshelters in Southwest Queensland. Memoirs of the Queensland Museum. 38(2):643-666.

ROBINS. R and TRIGGER, D. 1989 A Recent Phase of Aboriginal Occupation in Lawn Hill Gorge: A Case Study in Ethnoarchaeology. Australian Archaeology. 29:39-51

SMITH, M.A., WILLIAMS, E. and WASSON, RJ. 1991 The JSN site: some implications for the dynamics of human occupation in the Strzelecki Desert during the late Pleistocene. Records of the Australian Museum. 25(2):175-192.

VETH, P., HAMM, G. and LAMPERT, R.J. 1990 The archaeological significance of the Lower Cooper Creek. Records of the Australian Museum 24:43-66.

WRIGHT, M.J. 1983 Red-brown pans and associated soils in Australia. Transactions of the Royal Society of South Australia, 107(3):252:254. 